\title{
Projection of winter NPO-following winter ENSO connection in a warming climate: uncertainty due to internal climate variability
}

\author{
Shangfeng Chen ${ }^{1}$ (D) $\cdot$ Bin $\mathrm{Yu}^{2}$
}

Received: 24 December 2019 / Accepted: 25 June 2020 / Published online: 8 July 2020

(C) The Author(s) 2020

\begin{abstract}
Previous observational and modeling studies indicate that the wintertime North Pacific Oscillation (NPO) could significantly impact the following winter El Niño-Southern Oscillation (ENSO) variability via the seasonal footprinting mechanism (SFM). This study explores climate projections of this winter NPO-ENSO relation in a warming climate based on a 50-member large ensemble of climate simulations conducted with the second-generation Canadian Earth System Model (CanESM2). The ensemble mean of the 50 members can well reproduce the observed winter NPO pattern, the NPO-ENSO relationship, and the SFM process over the historical period 1950-2003. These 50 members are then employed to examine climate projections of the NPO-ENSO connection over the anthropogenic forced period 2020-2073. Results indicate that there exists a large spread of projected NPO-ENSO connections across these 50 ensemble members due to internal climate variability. Internal climate variability brings uncertainties in the projection of the winter NPO-ENSO connection originally seen in projected changes of the subtropical center of the winter NPO. The spread of projections of winter NPOassociated atmospheric anomalies over the subtropical North Pacific further results in various responses in the projections of winter and spring precipitation anomalies over the tropical North Pacific, as well as spring zonal wind anomalies over the tropical western Pacific, which eventually lead to uncertainties in the projection of the sea surface temperature anomalies in the tropical central-eastern Pacific from the following summer to winter.
\end{abstract}

Keywords $\mathrm{NPO} \cdot \mathrm{ENSO} \cdot \mathrm{Climate}$ projection $\cdot$ Uncertainty $\cdot$ Internal climate variability

Electronic supplementary material The online version of this article (https://doi.org/10.1007/s10584-02002778-3) contains supplementary material, which is available to authorized users.

Shangfeng Chen

chenshangfeng@mail.iap.ac.cn

Extended author information available on the last page of the article 


\section{Introduction}

The El Niño-Southern Oscillation (ENSO) is the dominant mode of the atmosphere-ocean coupled climate variability in the tropical Pacific on the interannual timescale (Bjerknes 1969; Philander 1990; Alexander et al. 2002). ENSO exerts considerable impacts on variations of weather and climate, marine ecosystems, and agriculture, as well as human health over many portions of the world (e.g., Gray 1984; Chiang and Sobel 2002; McPhaden 2002; Kovats et al. 2003; Huang et al. 2004; Chan 2005; Graf and Zanchettin 2012; Chen et al. 2013; Oluwole 2015; Song et al. 2017; McGregor and Ebi 2018; Chen and Song 2019; and references therein). For instance, the catastrophic Yangtze River floods in the summer of 1998, which have been attributed largely to the strong 1997/1998 El Niño, resulted in substantial economic loss and many casualties (Huang et al. 1998; Lau and Weng 2001). The strong 2015/2016 El Niño was also reported to exert pronounced influences on the crop growth and occurrences of extreme precipitation and temperature events over many regions (Zhai et al. 2016). More than 60 million people worldwide were affected by this strong El Niño event, as reported by the World Health Organization (http://www.who.int/news-room/feature-stories/detail/el-niñoaffects-more-than-60-million-people). During an El Niño (La Niña) winter, East Asian winter monsoon tends to be weaker (stronger) than normal, leading to above (below)-normal surface temperatures over many regions in East Asia (Wang et al. 2000; Wu et al. 2003; Huang et al. 2004). Meanwhile, the winter El Niño-induced anomalous anticyclone over the western North Pacific would maintain from winter to the following summer via positive air-sea feedbacks, and through modulating sea surface temperature (SST) anomalies in the Indian and Atlantic Oceans, which further influences the following summer East Asian climate (Wang et al. 2000; Xie et al. 2009; He and Wang 2013; Wang et al. 2013; Chen et al. 2018 ; Zhao et al. 2019). In addition, variations of weather and climate over North America, South America, and Indian monsoon regions are also significantly modulated by ENSO events via the ENSO-induced tropical circulation anomaly and atmospheric teleconnections (e.g., Mo 2000; Ashok and Guan 2004; Yu and Zwiers 2007). Given remarkable impacts of ENSO on the global climate, it is of great importance to investigate the factors contributing to the ENSO occurrence.

It is well known that the ocean-atmosphere interaction and oceanic dynamics play crucial roles in modulating the ENSO variability. In particular, a small perturbation of SST warming (cooling) in the tropical central-eastern Pacific could maintain and develop into an El Niño (La Niña) event through a positive atmosphere-ocean feedback process (Bjerknes 1969). Meanwhile, oceanic dynamics in the tropical Pacific, in particular, the equatorial eastward propagation of Kelvin waves and westward propagation of Rossby waves, are crucial for the phase transition of an ENSO cycle (Battisti and Hirst 1989; Jin 1997).

In addition to processes within the tropical Pacific, studies indicated that atmospheric forcings over the extratropics also play non-negligible roles in the ENSO occurrence (Li 1990; Vimont et al. 2001, 2003a, b; Nakamura et al. 2006, 2007; Chen et al. 2014, 2016, 2017; Ding et al. 2015; Yeh et al. 2015; Wang et al. 2019a, b). Among them, the boreal winter North Pacific Oscillation (NPO), a dominant mode of atmospheric variability over the extratropical North Pacific (Wallace and Gutzler 1981), has been found to be a significant contributor to the subsequent winter ENSO occurrence through the so-called seasonal footprinting mechanism (SFM; Vimont et al. 2001, 2003a; Alexander et al. 2010; Wang et al. 2019a, b). Previous studies indicated that the impact of the winter NPO on the following winter ENSO is independent of the ENSO cycle (Vimont et al. 2001, 2003a). Furthermore, Vimont et al. 
(2003b) found that the winter NPO would explain approximately $20-40 \%$ of the interannual ENSO variability by analyzing climate model simulations conducted with a coupled generation circulation model from the Commonwealth Scientific and Industrial Research Organization (CSIRO). Several other studies have also evaluated the ability of the 5th phase of the Coupled Model Intercomparison Project (CMIP5) climate models in reproducing the NPOENSO relation and associated SFM processes (e.g., Deser et al. 2012a; Wang et al. 2019a). Yet the future climate change projection of the NPO-ENSO relationship in a warming climate has not been explored.

In this study, we explore the projected change of the winter NPO-ENSO relation using a 50-member ensemble of climate simulations conducted with the second-generation Canadian Earth System Model (CanESM2) (Kirchmeier-Young et al. 2017; Rondeau-Genesse and Braun 2019). The performance of the NPO-ENSO relationship in CanESM2 has been examined in a recent study using its historical simulations (Chen and Yu 2019, manuscript submitted). It is found that the multi-member ensemble (MME) mean of the 50-member ensemble simulations can well reproduce the observed winter NPO-ENSO connection. The SFM process linking the winter NPO to the following winter ENSO can also be well simulated by the MME. However, there exists a large diversity in the NPO-ENSO relation across ensemble members due to internal climate variability. In this follow-up study, we use these 50 ensemble members to explore projections of the NPO-ENSO connection in a warming climate, the role of internal climate variability on this projected relationship, and potential factors leading to the projected uncertainty.

\section{Data and methods}

This study employs the monthly mean sea level pressure (SLP) from the National Centers for Environmental Prediction-National Center for Atmospheric Research reanalysis (NCEPNCAR) with a horizontal resolution of $2.5^{\circ} \times 2.5^{\circ}$ (Kalnay et al. 1996) and monthly mean SST data from the National Oceanic and Atmospheric Administration (NOAA) Extended Reconstructed SST version 3b (ERSSTv3b) dataset (Smith et al. 2008) on a $2.0^{\circ} \times 2.0^{\circ}$ grid. The analysis period is from January 1950 to December 2003. For convenience, the ERSSTv3b SST and NCEP-NCAR reanalysis data are referred to as "observational" data in the following.

The climate model data we employed are 50-member ensemble climate simulations from the CanESM2, which is a fully coupled atmosphere-ocean-land-sea ice general circulation model (Christian et al. 2010; Arora et al. 2011; Sigmond and Fyfe 2016). Specifically, five simulations are firstly performed for the period of 1850-1950 to produce five different oceanic states in 1950. Ten experiments are then run from each of the above five historical simulations with slightly different initial conditions in 1950, generating a total of 50 ensemble members of 150 -year simulations for the period of 1950-2100. Due to the chaotic natures of the climate system, the slightly different initial condition in 1950 can quickly lead to different atmospheric states a few days later (Deser et al. 2012a; Wallace et al. 2014; Kay et al. 2015). Each of the simulations is forced with the same historical greenhouse gas concentration, sulfate aerosols, and other radiative forcings from 1950 to 2005 . From 2006 to 2100 , the simulations are forced by the representative concentration pathway 8.5 forcing (RCP8.5, van Vuuren et al. 2011). The CanESM2 simulations have a horizontal resolution of about $2.8^{\circ} \times 2.8^{\circ}$ in longitude-latitude grids. 
Following previous studies (Linkin and Nigam 2008; Yu and Kim 2011; Park et al. 2013; Chen and Wu 2018), the NPO index is defined as the principal component (PC) time series corresponding to the second empirical orthogonal function (EOF) mode of SLP anomalies over the North Pacific region $\left(20-60^{\circ} \mathrm{N}, 120^{\circ} \mathrm{E}-120^{\circ} \mathrm{W}\right)$. Slight changes of the domain used in the EOF analysis would not change the NPO pattern and its variability. The positive phase of the NPO pattern is associated with positive SLP anomalies over the mid-latitude North Pacific and negative SLP anomalies over the subtropical North Pacific. The Niño-3.4 index, which is the regional mean SST anomalies over $5^{\circ} \mathrm{S}-5^{\circ} \mathrm{N}$ and $120-170^{\circ} \mathrm{W}$, is employed to represent the tropical ENSO variability.

In this study, projected changes are defined as differences between the two periods of 2020-2073 and 1950-2003 (both containing 54 years as in the observation). MME is calculated as the average of variables of interest from each ensemble member with equal weight. Since the analysis focuses on the interannual NPO-ENSO relationship, all time series considered are subjected to a 2-9-year bandpass filter to remove their interdecadal variations and long-term trend. Significance levels of regression and correlation coefficients are assessed based on a two-tailed Student's $t$ test. In addition, following previous studies (Deser et al. 2012c; Kucharski and Joshi 2017; Zheng et al. 2018; Joshi and Ha 2019), MME anomalies obtained from regression analyses are significant at the $95 \%$ confidence level when they meet the following criterion:

$$
\mid M M E_{-} \text {var } \mid \geq \frac{s t d_{-} v a r \times \lambda}{\sqrt{N}}
$$

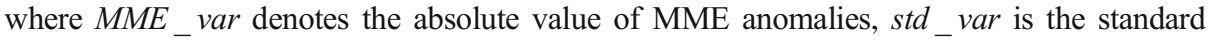
deviation of the anomalies among the multi-members considered, $\lambda$ is equal to 2, and $N$ indicates the number of ensemble members.

Furthermore, we employ the Fisher's $r$ - $z$ transformation method (Fisher 1921; Meng et al. 1992; Chen et al. 2020) to estimate the significance level of the correlation differences between two group members.

\section{Winter NPO-ENSO relationship in CanESM2 historical simulations}

Figure 1a shows correlation coefficients between the winter $(\mathrm{ND}(-1) \mathrm{JFM}(0)) \mathrm{NPO}$ index and its following winter $(\mathrm{D}(0) \mathrm{JF}(+1))$ Niño-3.4 index from 1950/1951 to 2003/2004 for the 50 CanESM2 ensemble members. Here " -1, , " 0 ," and " +1 ” denote the preceding, simultaneous, and following years, respectively. Majority of the ensemble members (i.e., 39 members) can produce a significant relation of the winter NPO with the following winter ENSO (Fig. 1a). The MME of the correlation coefficients between the winter NPO index and following winter Niño-3.4 index for the 50 members is about 0.35 , which is statistically significant at the $95 \%$ confidence level (Fig. 1a). The observed winter NPO and its associated ENSO-like patterns in the following winter (Figs. 2a, b) are also reasonably well simulated by the MME of these 50 members over the historical simulation period (Figs. 2c, d). In addition, ND(-1)JFM(0) SLP anomalies in association with the $\mathrm{D}(0) \mathrm{JF}(+1)$ Niño-3.4 in most of the 50 members and their MME display an NPO-like dipole pattern over the North Pacific (please see Supplementary Fig. S1). The above evidences indicate that the MME of the 50 members can well reproduce the observed significant relation of the winter NPO with the following winter ENSO. 
Figure 3 further presents the simultaneous winter SLP anomalies regressed upon the normalized winter NPO index over 1950-2003 for the 50 individual members and their MME. Spatial distributions of the winter SLP anomalies for all these 50 members bear resemblance to the observed NPO pattern (Fig. 2a), and those described in previous studies (Vimont et al. 2001, 2003a, b; Linkin and Nigam 2008; Yu and Kim 2011; Park et al. 2013; Song et al. 2016). In particular, all these members capture the dipole SLP anomaly pattern over the North Pacific related to the NPO, with significant positive SLP anomalies over midlatitudes of the North Pacific, Alaska, and northwest part of Canada, and pronounced negative SLP anomalies over the subtropical North Pacific. Pattern correlation coefficients between the observed and simulated winter SLP anomalies over the North Pacific domain $\left(20-70^{\circ} \mathrm{N}, 120^{\circ}\right.$ $\mathrm{E}-120^{\circ} \mathrm{W}$ ) are above 0.65 for the 50 ensemble members (see Supplementary Fig. S2). This implies that all the ensemble members can well reproduce the observed NPO pattern (Fig. 2a). Nevertheless, differences, mainly in magnitude of the SLP anomalies, exist across the 50 members (Fig. 3).

(a)

Hist

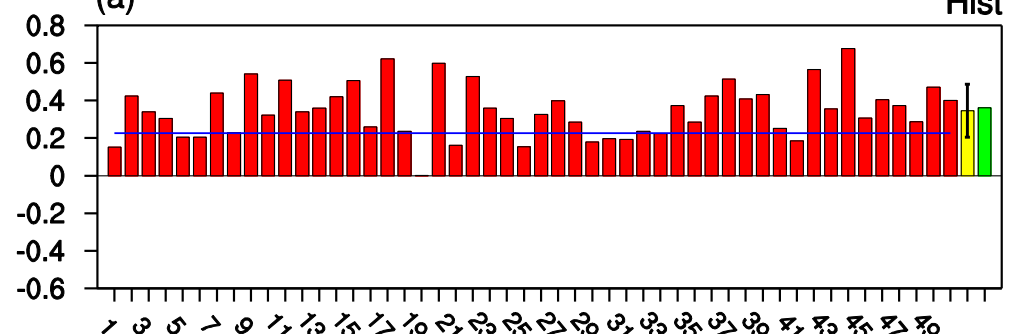

(b)

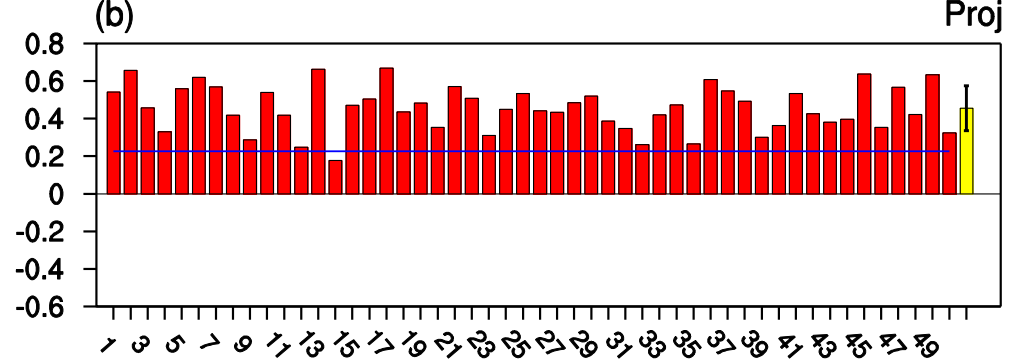

(c)

Proj minus Hist

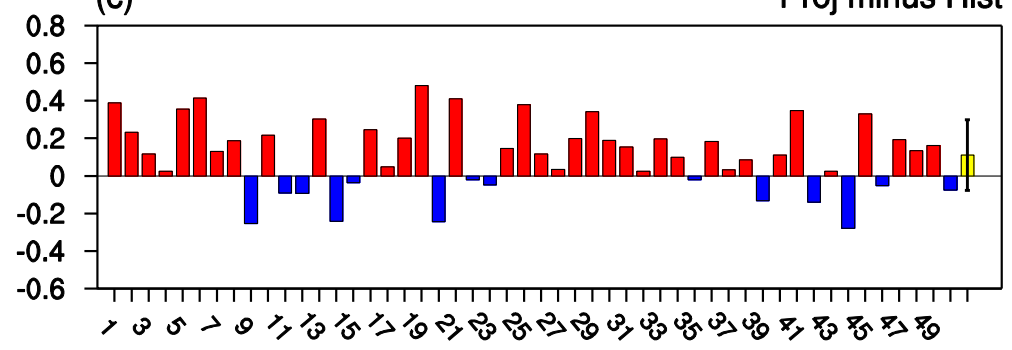

Fig. 1 a Correlation coefficients between the ND(-1)JFM(0) NPO index and its following winter $(D(0) \operatorname{JF}(+1))$ Niño-3.4 index over 1950-2003 for the 50 members and their MME (yellow bar). The blue line indicates the correlation significant at the $90 \%$ level. The error bar indicates one standard deviation of the correlation coefficients among the 50 members. The green bar represents the observed result. $\mathbf{b}$ as in $\mathbf{a}$, but for the period over 2020-2073. c Differences in the correlations of the winter NPO with its following winter Niño-3.4 between 2020-2073 and 1950-2003 for the 50 members and their MME. The error bar indicates one standard deviation of the differences among the 50 members 


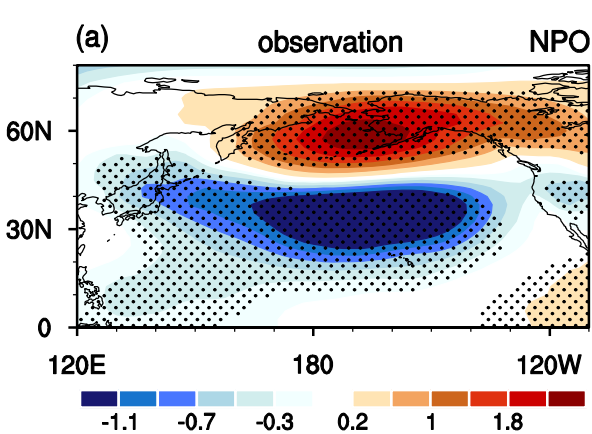

(b) observation ENSO

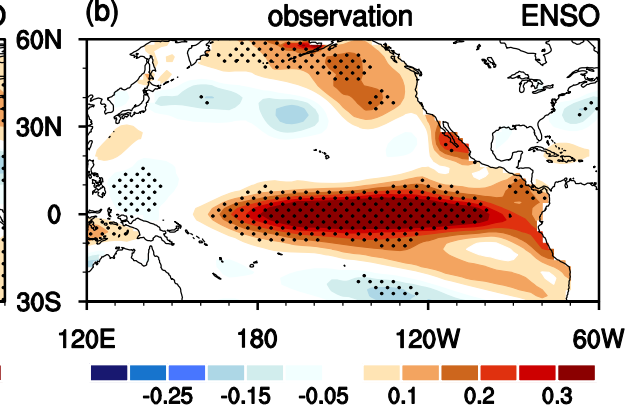

(c) current climate NPO
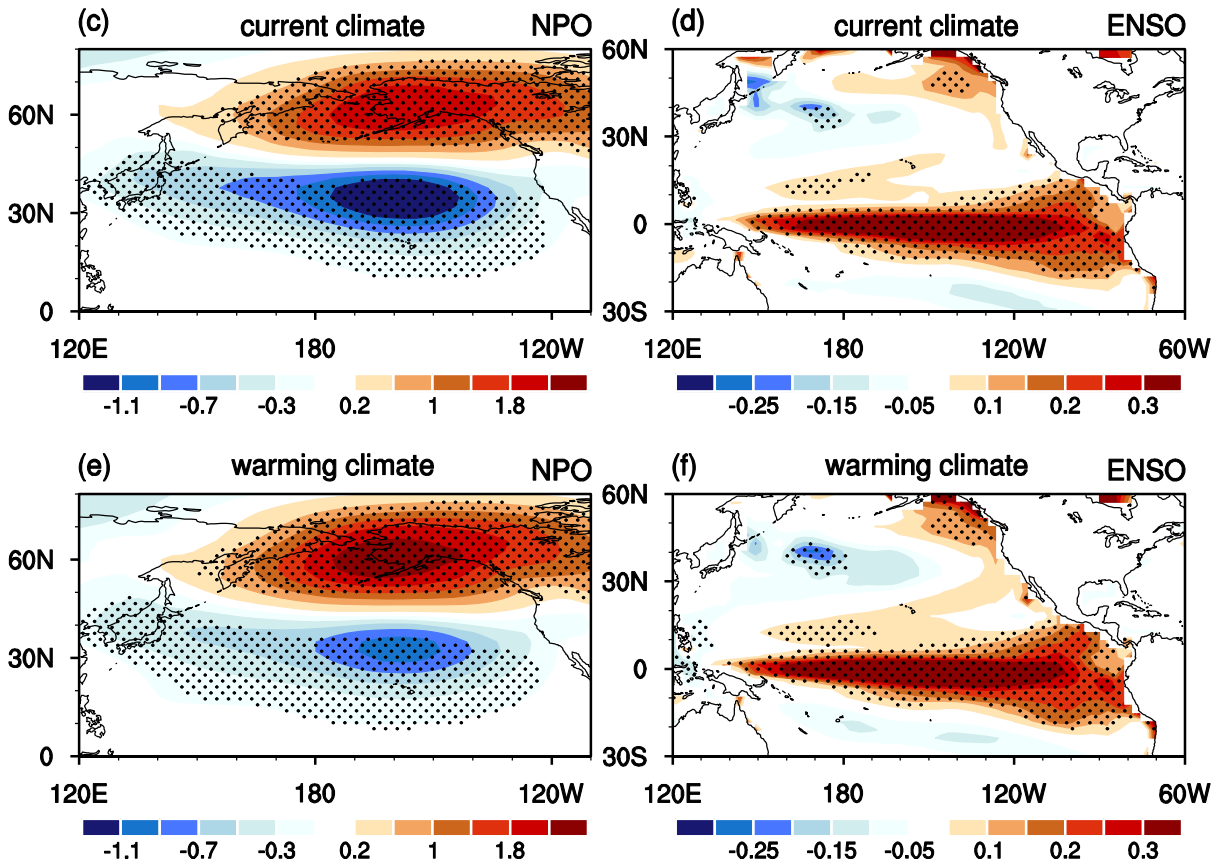

Fig. 2 a Winter $(\mathrm{ND}(-1) \mathrm{JFM}(0)) \mathrm{SLP}$ (unit: $\mathrm{hPa}$ ) and b following winter $(\mathrm{D}(0) \mathrm{JF}(+1)) \mathrm{SST}$ (unit: ${ }^{\circ} \mathrm{C}$ ) anomalies obtained by regression upon the normalized $\mathrm{ND}(-1) \operatorname{JFM}(0)$ NPO index based on observational data during period 1950-2003. c, d and e, f As in $\mathbf{a}, \mathbf{b}$, but for ensemble mean of the ND(-1)JFM(0) SLP and D $(0) J F(+1)$ SST anomalies regressed on the normalized ND(-1)JFM(0) NPO index for the 50 members of CanESM2 over 1950-2003 and 2020-2073, respectively

The observed physical process (i.e., the seasonal footprinting mechanism) linking the winter NPO to its following winter ENSO is also reasonably well reproduced in the ensemble mean of these 50 members. Figure 4 displays the ensemble means of the winter NPOassociated $850-\mathrm{hPa}$ wind and precipitation anomalies from the simultaneous winter to the following winter. Figure 5 shows the corresponding NPO-associated SST anomalies. At $\mathrm{ND}(-1) \operatorname{JFM}(0)$, a meridional dipole pattern of atmospheric anomalies appears in the North Pacific, with a significant anticyclonic anomaly over mid-latitudes and a pronounced cyclonic anomaly over the subtropics (Fig. 4a). Correspondingly, a marked dipole pattern of precipitation anomalies is observed over the North Pacific (Fig. 4a, color shading). The centers of positive and negative precipitation anomalies correspond well to the centers of anomalous 

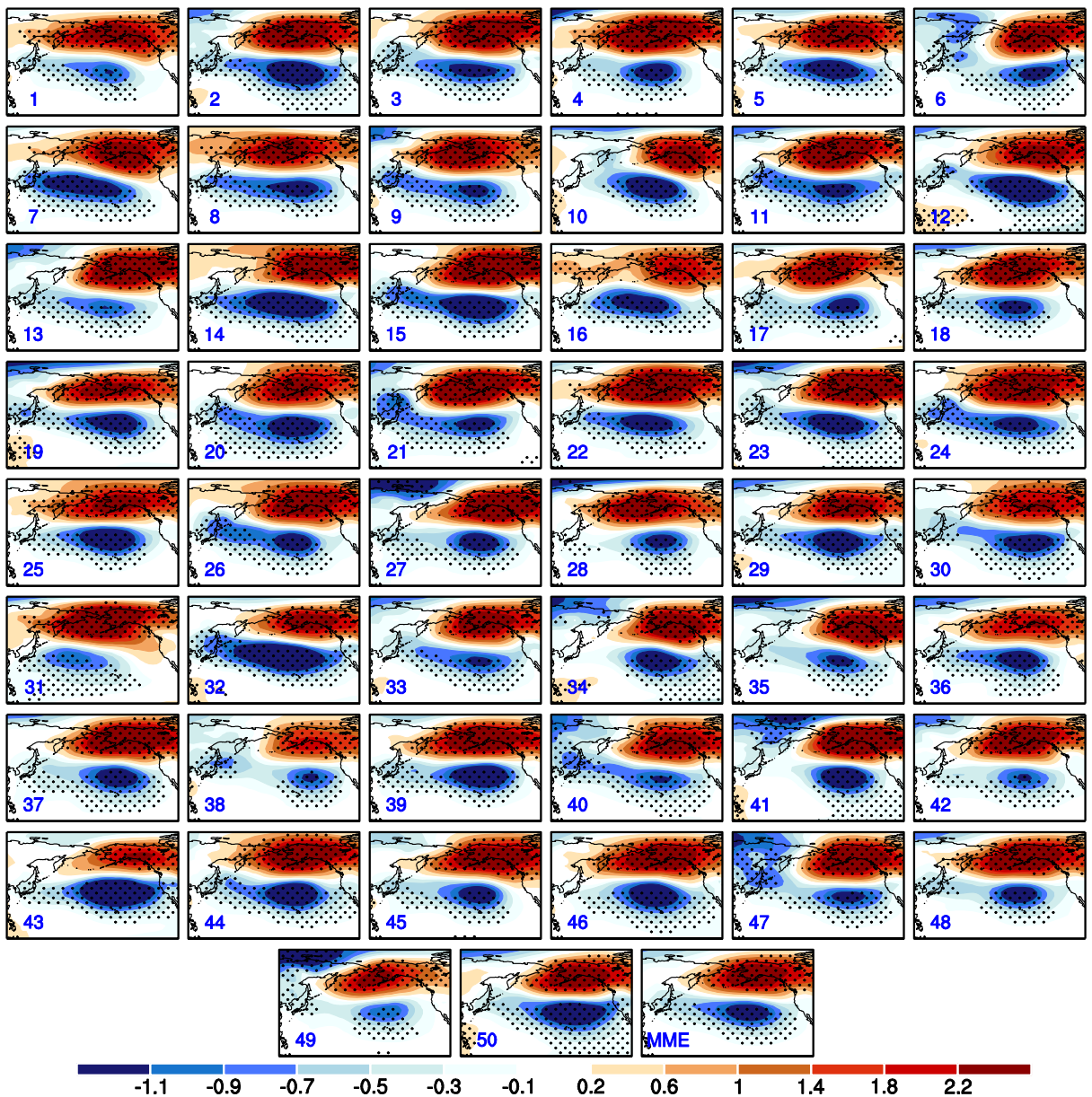

$-0.1$

0.2

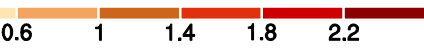

Fig. 3 Winter $(\mathrm{ND}(-1) \mathrm{JFM}(0)) \mathrm{SLP}$ anomalies (unit: $\mathrm{hPa}$ ) regressed upon the normalized simultaneous winter NPO index during 1950-2003 for each of the 50 members of CanESM2 and their MME. Stippling regions indicate SLP anomalies significant at the $95 \%$ confidence level

cyclone and anticyclone, respectively. Meanwhile, a tripole SST anomaly pattern is found in the simultaneous winter (Fig. 5a). As has been demonstrated in previous studies, the formation of the winter NPO-associated SST anomalies in the North Pacific is mainly attributed to the forcing of the overlying atmospheric circulation anomalies (Vimont et al. 2001, 2003a, b; Alexander et al. 2010). In particular, the southwesterly wind anomalies over the subtropical North Pacific reduce their climatological northeasterly winds (Fig. 4a) and contribute to SST warming there (Fig. 5a) via reducing upward surface net heat fluxes (Xie and Philander 1994; Vimont et al. 2001). The easterly wind anomalies over the mid-latitude North Pacific also reduce their climatological westerly winds (Chen et al. 2000), which result in SST warming there via reducing surface net heat flux. In addition, the anomalous easterly winds over the mid-latitude North Pacific would bring warmer ocean water northward via the Ekman transportation, which also contributes to SST warming there (Wu and Kinter 2010). By contrast, the northwesterly wind anomalies over the subtropical western North Pacific carry colder air southward from higher latitudes, increasing the surface evaporation and leading to SST cooling (Figs. 4a and 5a). 
At MAM(0), the significant SST warming in the subtropical North Pacific and tropical central Pacific is accompanied by pronounced positive precipitation anomalies, indicating enhanced atmospheric convection and heating, which in turn leads to strong westerly wind anomalies over the tropical western-central Pacific via a Gill-type atmospheric response (Figs. $4 \mathrm{~b}$ and $5 \mathrm{~b}$ ). These spring westerly wind anomalies over the tropical western-central Pacific would contribute to SST warming in the tropical central-eastern Pacific in the following summer by triggering eastward-propagating equatorial warm Kelvin waves, as demonstrated in previous studies (Barnett et al. 1989; Huang et al. 2001; Vimont et al. 2001; Nakamura et al. 2006; Chen et al. 2014). Subsequently, the SST warming in the tropical central-eastern Pacific would maintain and develop via the Bjerknes positive air-sea feedback mechanism in the following seasons (Figs. 4c-f and 5c-f). An El Niño-like pattern is eventually generated in the following winter (Figs. $4 \mathrm{f}$ and $5 \mathrm{f}$ ). Through the above-described processes, the wintertime NPO exerts an influence on the following winter ENSO occurrence. In addition, it should be mentioned that the SST anomalies at $\mathrm{ND}(-1) \operatorname{JFM}(0)$ in the tropical central-eastern Pacific are weak (Fig. 5a). This suggests that the impact of the winter NPO on the following winter ENSO is not due to the ENSO cycle. In general, results from the CanESM2 historical simulations are
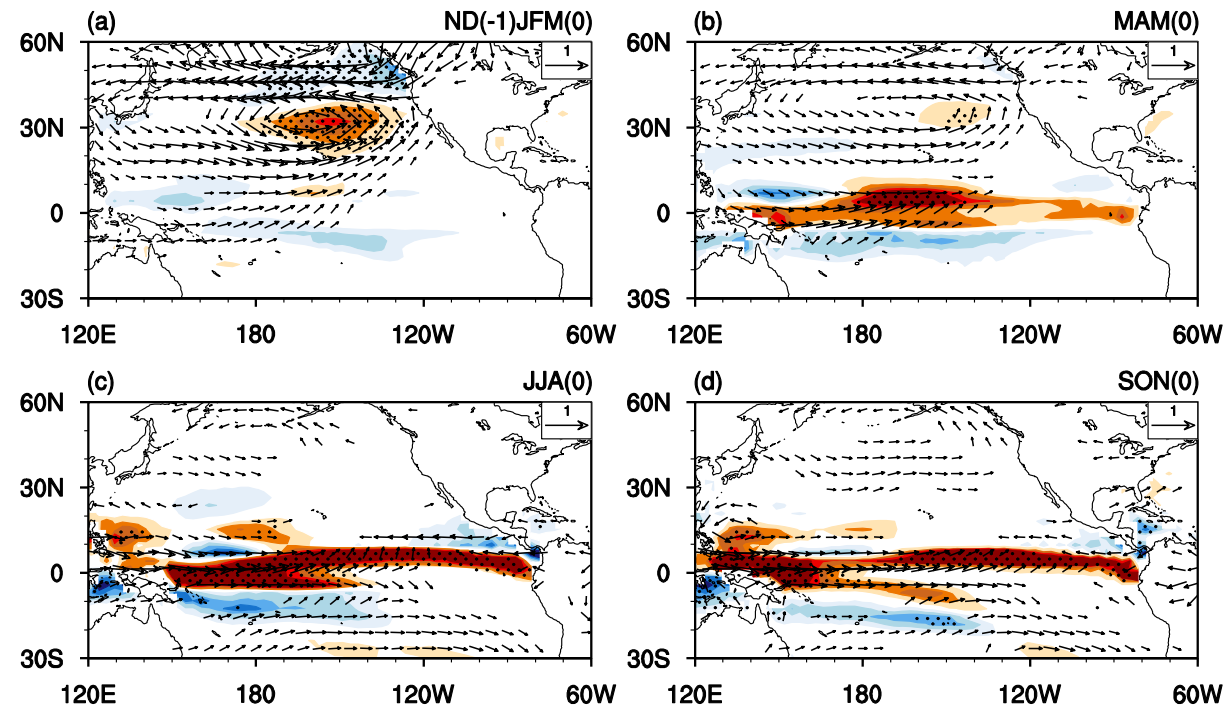

(d) $\operatorname{SON}(0)$
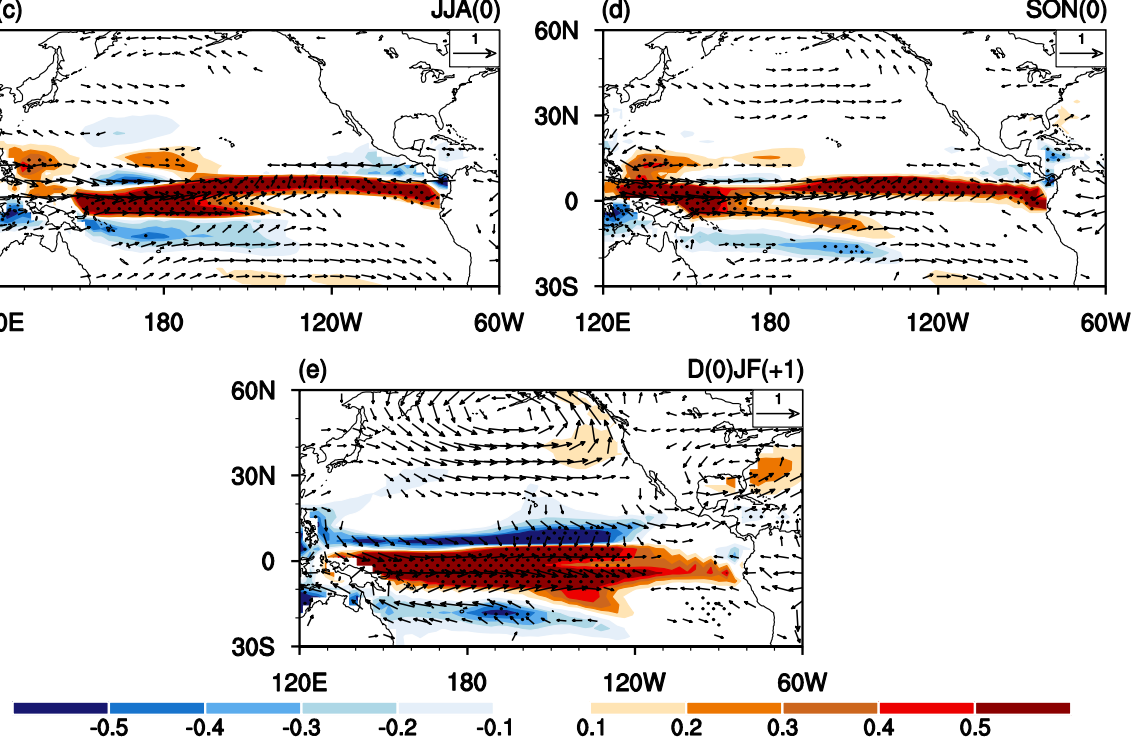

Fig. 4 Ensemble mean of the precipitation (shadings; unit: $\mathrm{mm} \mathrm{day}^{-1}$ ) and $850 \mathrm{hPa}$ wind (vectors; unit: $\mathrm{m} \mathrm{s}^{-1}$ ) anomalies at a $\mathrm{ND}(-1) \mathrm{JFM}(0), \mathbf{b} \mathrm{MAM}(0), \mathbf{c} \mathrm{JJA}(0)$, d SON $(0)$, and $\mathbf{e} \mathrm{D}(0) \mathrm{JF}(+1)$ regressed upon the normalized $\mathrm{ND}(-1) \mathrm{JFM}(0)$ NPO index during 1950-2003 for the 50 members of CanESM2. The stippling region indicates precipitation anomalies significant at the $5 \%$ level 


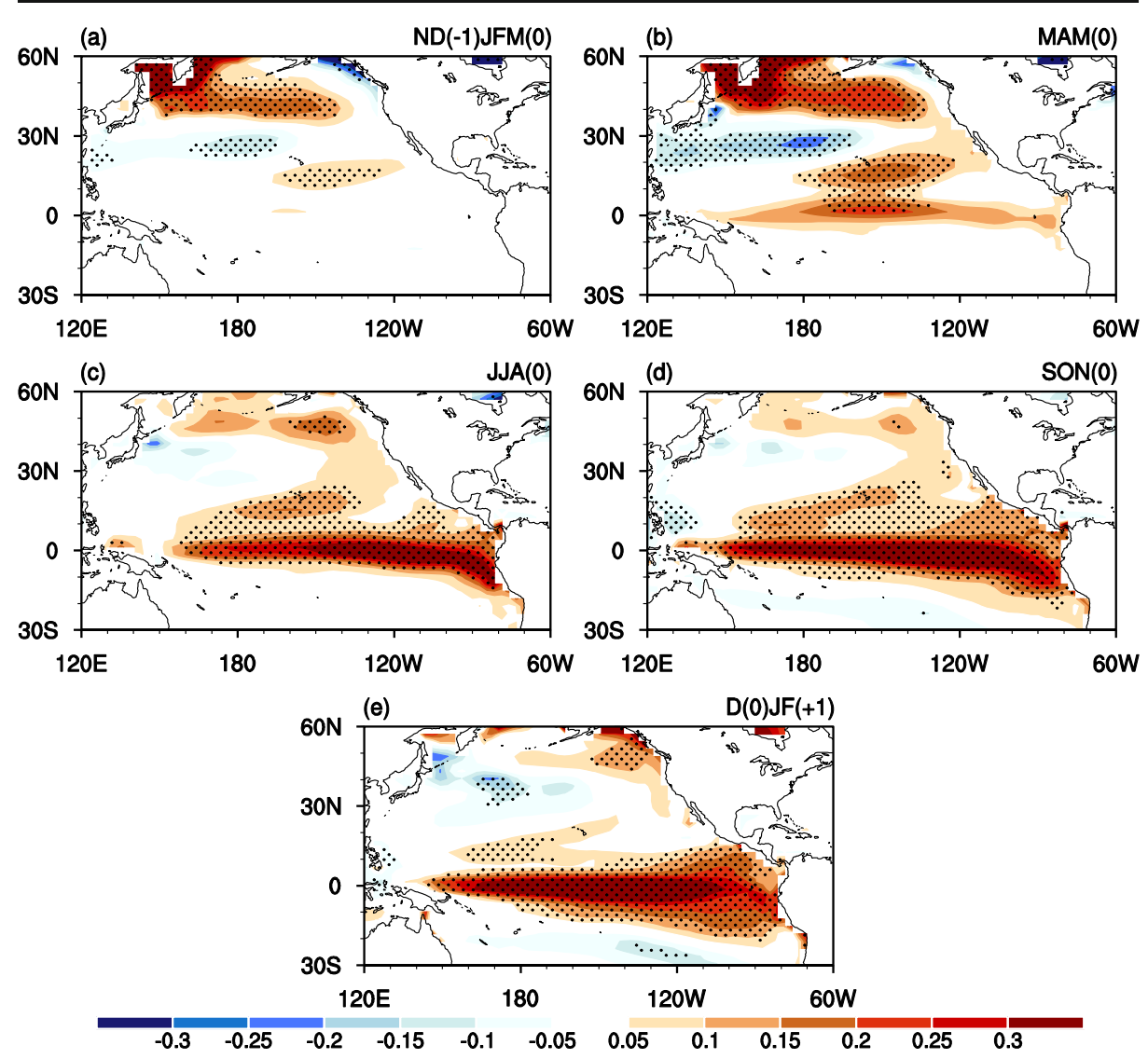

Fig. 5 Ensemble mean of the SST (unit: ${ }^{\circ} \mathrm{C}$ ) anomalies at a $\mathrm{ND}(-1) \operatorname{JFM}(0)$, b MAM(0), c JJA(0), d SON(0), and e $\mathrm{D}(0) \mathrm{JF}(+1)$ regressed on the normalized ND(-1)JFM $(0)$ NPO index during 1950-2003 for the 50 members of CanESM2. The stippling region indicates SST anomalies significant at the $95 \%$ confidence level

consistent with previous observational and modeling findings (Vimont et al. 2001, 2003a, b; Alexander et al. 2010).

Overall, the MME of the 50 members has a good ability in reproducing the observed winter NPO pattern as well as the seasonal footprinting mechanism for the impact of winter NPO on the following winter ENSO. Hence, in the following, we will explore projected changes of the winter NPO-ENSO relation in a warming climate based on their RCP8.5 forced simulations.

\section{Projected changes of the winter NPO-ENSO relationship}

Figure 1b compares correlation coefficients between the winter NPO index and its following winter Niño-3.4 index over 2020-2073 for the 50 members and their MME. The correlation coefficients are positive for all members over 2020-2073. The wintertime NPO-like atmospheric anomalies also have a close relation with an ENSO-like SST anomaly pattern in its following winter over 2020-2073 (Figs. 2e, f). These suggest that the significant NPO-ENSO relationship is still robust in a warming climate under the RCP8.5 scenario. In addition, the MME of the NPO-ENSO correlations for the 50 members over 2020-2073 is about 0.46, 
which is larger than that over 1950-2003 (0.35). Furthermore, seasonal evolutions of the MME SST, 850-hPa winds, and precipitation anomalies related to the winter NPO during 2020-2073 (see Supplementary Fig. S3 and Fig. S4) are very similar to those during 19502003 (Figs. 4 and 5). This indicates that the physical processes for the impact of the winter NPO on the following winter ENSO are similar between the current and warming climates. We have also examined running correlations of the winter NPO index with the following winter Niño-3.4 index with a length of a 31-year window over 1950-2100 (see Supplementary Fig. S5). The MME of the running correlations shows a slight enhancement of the NPO-ENSO connection with global warming (Fig. S5 in the Supplementary). However, there exist large diversities of correlation changes among the 50 members (Figs. 1a, b, and Fig. S5).

Figure 1c further shows differences in the correlation of the NPO-ENSO relationships between 2020-2073 and 1950-2003 for the 50 members. The difference series is referred to as the CC_Diff index in the following of this analysis. The CC_Diff index reveals that 36 out of the 50 ensemble members project an increase of the winter NPO-ENSO connection, while the others produce a weakened NPO-ENSO connection (Fig. 1c). Furthermore, the MME of the CC_Diff index over the 50 members is 0.11 , while the standard deviation of the CC_Diff index is approximately 0.19 across the 50 members. This indicates that there exists a large uncertainty in the projected change of the winter NPO-ENSO relation in a warming climate. As each of the CanESM2 ensemble members is forced by identical external forcing and with only slight differences in the initial condition, the spread of the projection of the NPO-ENSO connection among the 50 members is due solely to internal climate variability (e.g., Deser et al. 2012b, 2014).

What are the possible processes in association with this projected uncertainty? Previous studies indicated that the subtropical center of the NPO plays a crucial role in relaying impacts of the winter NPO on its following winter ENSO (Park et al. 2013; Chen and Wu 2018; Chen and Yu 2019, submitted). Hence, we first examine the projected change of the winter NPOassociated SLP anomalies over the North Pacific. For brevity, we focus on comparing the members with large differences in the projection of the NPO-ENSO relationship in the following analysis. Specifically, we choose 10 members with the highest values of the CC_Diff index (denoted as group A) and 10 members with the lowest values of the CD_Diff index (denoted as group B). Group A members project an increase in the NPO-ENSO relation, whereas group B members project a weakened NPO-ENSO relation. Results obtained in the following analysis are not sensitive to slight changes of the number of selected members used in group A and group B.

Figure 6a shows differences in the projected changes of the winter NPO-related simultaneous winter SLP anomalies between group A and group B members. Significant negative SLP anomalies are seen over the subtropical North Pacific around $10-22.5^{\circ} \mathrm{N}$ and $170^{\circ} \mathrm{E}-$ $130^{\circ} \mathrm{W}$. Figure $6 \mathrm{~b}$ further presents a scatterplot of the CC_Diff index versus projected changes in the winter NPO-related $\mathrm{ND}(-1) \mathrm{JFM}(0) \mathrm{SLP}$ anomalies averaged over $10-20^{\circ} \mathrm{N}, 150-180^{\circ}$ $\mathrm{W}$ (box in Fig. 6a) among the 50 members. The correlation coefficient between the two quantities in Fig. 6 b is about -0.54 among the 50 ensemble members, significant at the $99 \%$ confidence level. This suggests that the uncertainty in the projection of the winter NPO-ENSO relation has a close relation with the spread in the projection of the southern center of the winter NPO pattern among the 50 members. The ensemble member with an enhancement (a weakening) of the winter NPO's southern center tends to project an increase (a decrease) in the winter NPO-ENSO connection in a warming climate. Differences in the projected changes of the NPO-related SLP anomalies over mid-latitudes of the North Pacific are statistically 
insignificant (Fig. 6a). This suggests that the uncertainty in the projection of the winter NPOENSO relation is not related to the spread of the northern center of the winter NPO.

Previous studies indicated that westerly wind anomalies over the tropical western Pacific, as well as precipitation and SST anomalies in the tropical central North Pacific, in seasons following the NPO winter are also important in linking winter NPO with its following winter ENSO (e.g., Vimont et al. 2001, 2003a, b; Chen et al. 2013, 2014). Hence, we further examine differences in the anomalies of projected changes in the winter NPO-associated precipitation and $850-\mathrm{hPa}$ wind anomalies at $\mathrm{ND}(-1) \operatorname{JFM}(0), \operatorname{MAM}(0), \operatorname{JJA}(0), \operatorname{SON}(0)$, and $\mathrm{D}(0) \mathrm{JF}(+1)$ between group $\mathrm{A}$ and group $\mathrm{B}$ members (Fig. 7). Figure 8 displays the corresponding differences in the winter NPO-related SST anomalies. From Fig. 7, large anomalies in association with the CC_Diff index are seen in the winter and spring precipitation changes over the tropical Pacific, as well as spring westerly wind changes over the tropical westerncentral Pacific. The scatterplots of the CC_Diff index versus projected changes in the winter NPO-related winter precipitation anomalies averaged over $5-10^{\circ} \mathrm{N}, 155-175^{\circ} \mathrm{W}$; spring precipitation anomalies averaged over $0-5^{\circ} \mathrm{N}, 175^{\circ} \mathrm{E}-145^{\circ} \mathrm{W}$; and spring $850-\mathrm{hPa}$ zonal wind anomalies averaged over $5^{\circ} \mathrm{S}-5^{\circ} \mathrm{N}, 160^{\circ} \mathrm{E}-160^{\circ} \mathrm{W}$ are further presented in Fig. $9 \mathrm{a}-\mathrm{c}$,

Fig. 6 a Differences (unit: $\mathrm{hPa}$ ) in the projected changes of the winter NPO-related simultaneous winter SLP anomalies between group A and group B members. Stippling regions in the figure indicate the differences that are significantly different from zero at the $95 \%$ confidence level. b Scatterplot of the CC_Diff index versus projected changes in the winter NPO-related ND(-1)JFM(0) SLP anomalies averaged over 10-22.5 $\mathrm{N}$ and $170^{\circ} \mathrm{E}-130^{\circ} \mathrm{W}$ (black box in a). Definitions of group A and B members are described in the text
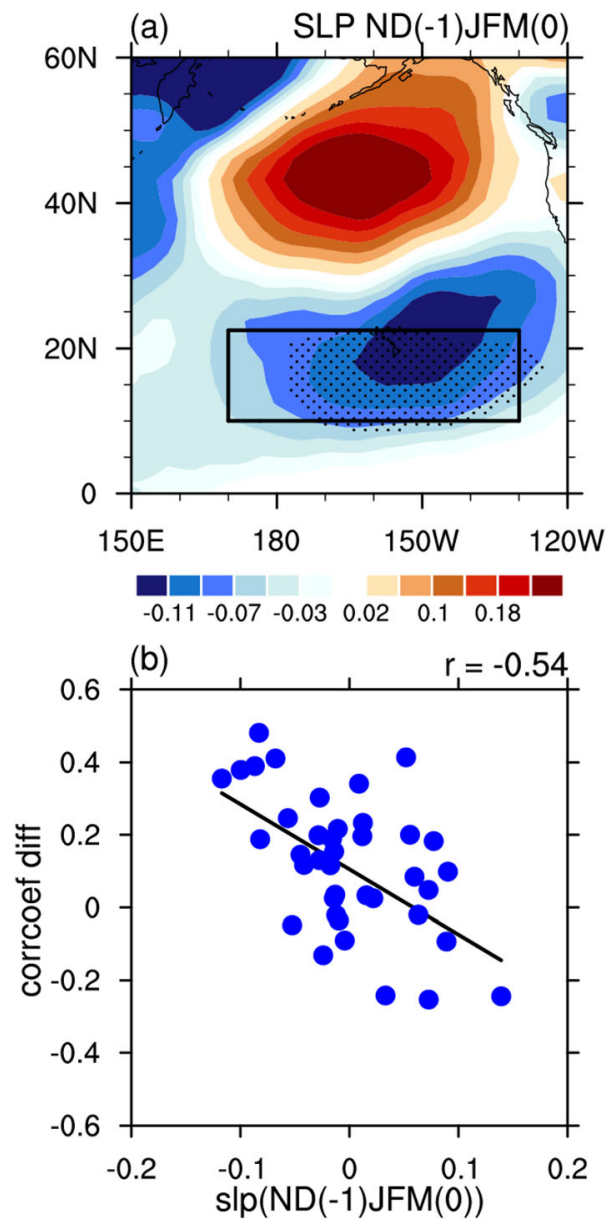
respectively. The regions used in these scatterplots are chosen according to the results in Fig. 7a, b. The correlation coefficients between the two quantities in Fig. 9a-c, as marked with each plot, are statistically significant at the $95 \%$ confidence level.

Differences in the projected SST changes between group A and group B members are weak over most parts of the Pacific in winter and spring (Fig. 8a, b). A pronounced El Niño-like pattern starts to appear in the tropical central-eastern Pacific in the following summer (Fig. 8c). Figure 9d further shows a scatterplot of the CC_Diff index versus projected changes in the winter NPO-related summer SST anomalies averaged over $5^{\circ} \mathrm{S}-5^{\circ} \mathrm{N}, 120-180^{\circ} \mathrm{W}$ (box in Fig. 8c). The correlation coefficient between the two quantities in Fig. $9 \mathrm{~d}$ is as high as 0.83 . Previous observational and modeling studies have demonstrated that spring westerly wind anomalies over the tropical western Pacific can lead to SST warming in the tropical centraleastern Pacific in the following summer via triggering eastward-propagating warm Kelvin waves (Barnett et al. 1989; Huang et al. 2001; Vimont et al. 2003a, b; Nakamura et al. 2006; Chen et al. 2014, 2017). This suggests that the appearance of the El Niño-like pattern in summer (Fig. 8c) is likely related to the spring westerly wind anomalies over the tropical western Pacific (Fig. 7b). The significant El Niño-like pattern sustains and enhances from
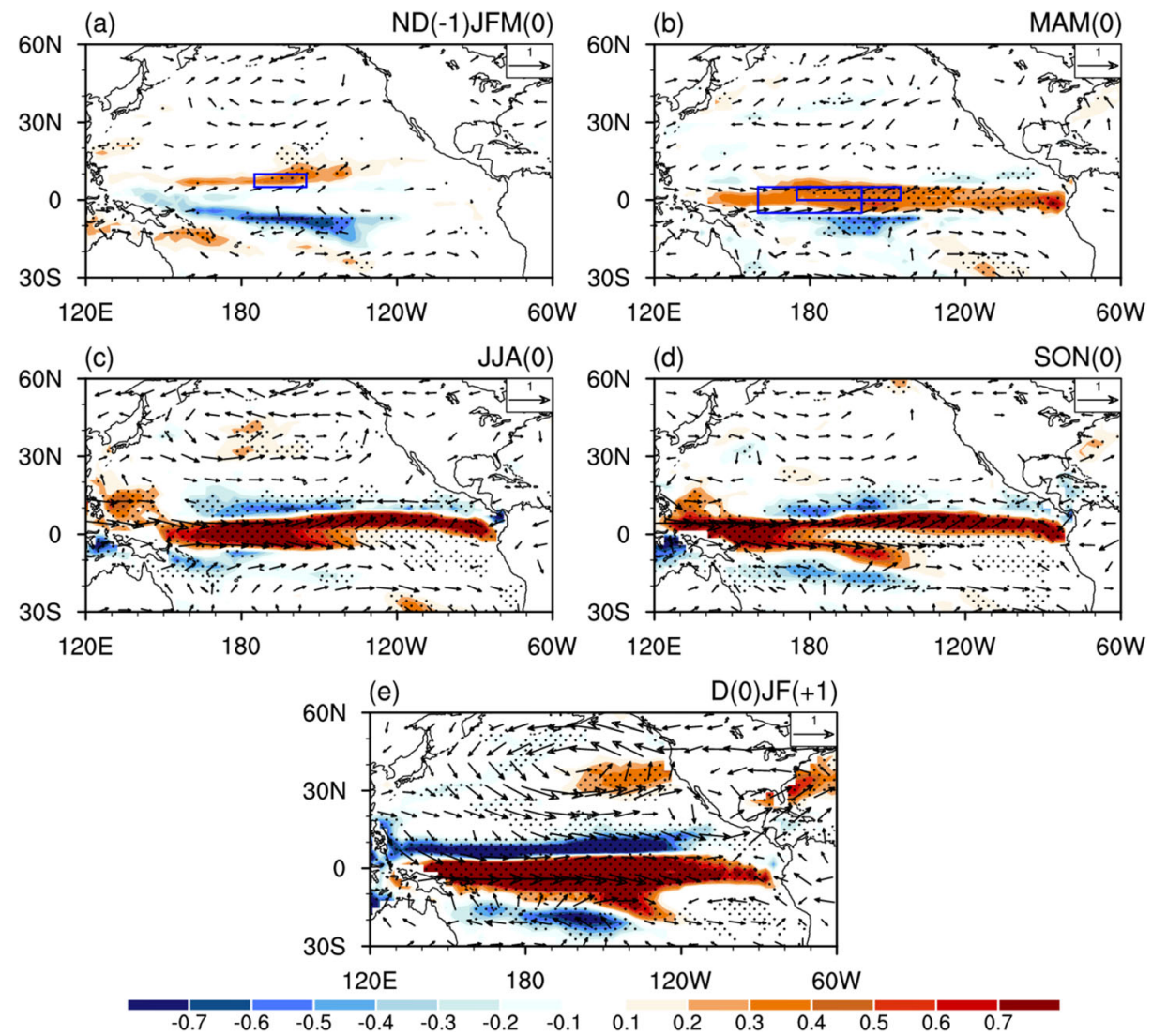

Fig. 7 Differences in the projected changes of the winter NPO-related precipitation (unit: $\mathrm{mm}^{\mathrm{day}}{ }^{-1}$ ) and $850 \mathrm{hPa}$ wind (unit: $\mathrm{m} \mathrm{s}^{-1}$ ) anomalies at a $\mathrm{ND}(-1) \mathrm{JFM}(0)$, b MAM(0), c JJA(0), d SON(0), and e $\mathrm{D}(0) \mathrm{JF}(+1)$ between group A and group B members. Stippling regions in the figure indicate differences in precipitation that are significantly different from zero at the $95 \%$ confidence level 

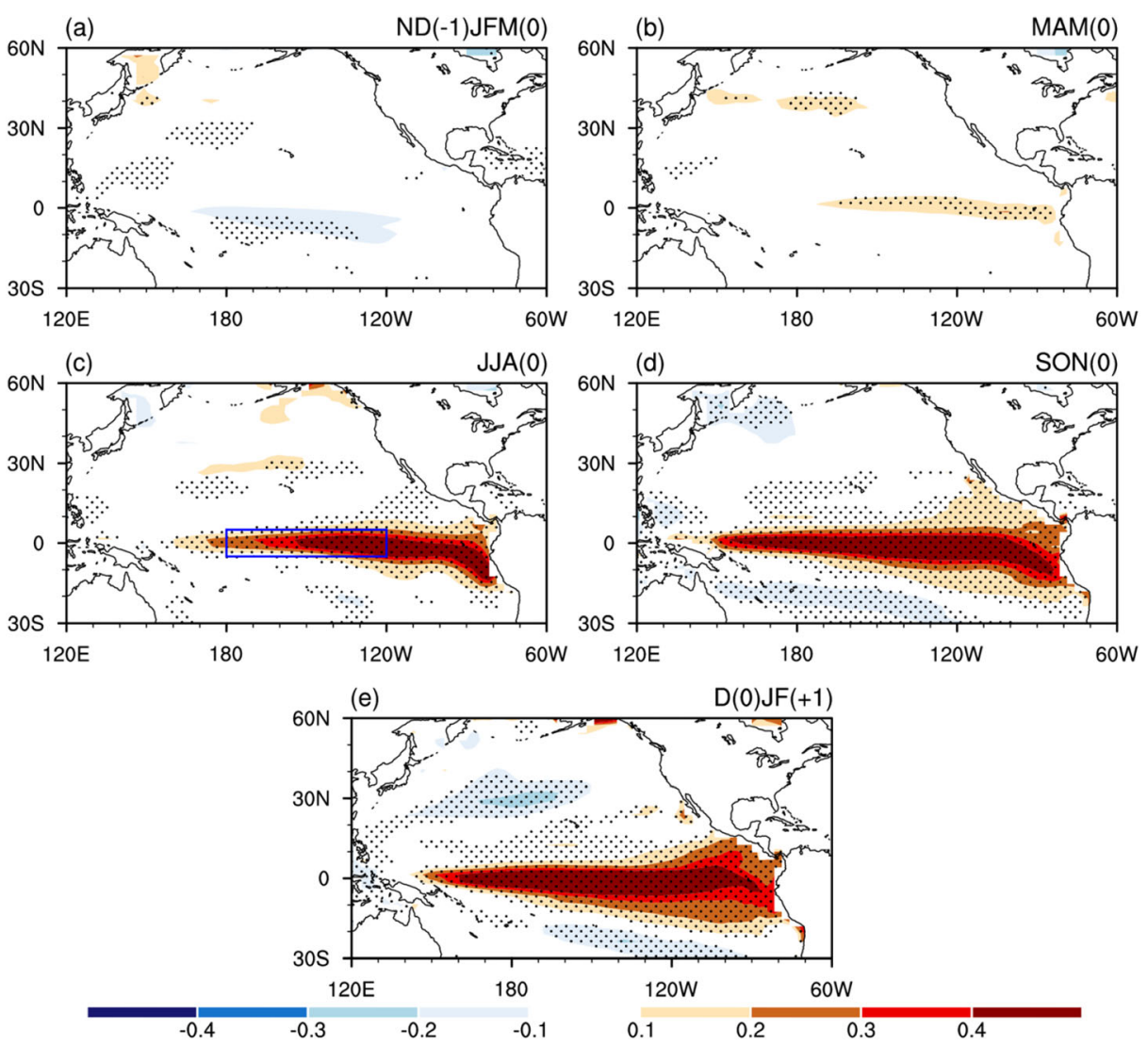

Fig. 8 Differences (unit: ${ }^{\circ} \mathrm{C}$ ) in the projected changes of the winter NPO-related SST anomalies at a $\mathrm{ND}(-1) \mathrm{JFM}(0), \mathbf{b} \mathrm{MAM}(0)$, $\mathbf{c} \mathrm{JJA}(0)$, d $\operatorname{SON}(0)$, and e $\mathrm{D}(0) \mathrm{JF}(+1)$ between group A and group B members. Stippling regions in the figure indicate the differences that are significantly different from zero at the $95 \%$ confidence level

summer to winter (Figs. 8d, e), mainly attributed to the positive Bjerknes feedback mechanism in the tropical Pacific, as demonstrated in previous studies (e.g., Vimont et al. 2001, 2003a, b; Chen et al. 2014).

From the above analysis, we conclude that internal climate variability may lead to large spreads of the projected changes of the winter NPO-associated atmospheric circulation anomalies over the subtropical North Pacific, the projection of the NPO-related winter and spring precipitation anomalies over the tropical North Pacific, and spring zonal wind anomalies over the tropical western Pacific. The uncertainty in the projected springtime low-level zonal wind anomalies over the tropical western Pacific further results in the formation of an El Niño-like pattern during summer, which sustains and enhances into the following winter.

Note that projected changes in the NPO-ENSO relation may also be affected by projections of the ENSO's characteristics, such as its amplitude, spatial pattern, and phase locking. ENSO tends to reach its peak phase in boreal winter (e.g., Wang et al. 2000). The amplitude of an ENSO event could be represented by SST anomalies averaged in the Niño-3.4 region $\left(5^{\circ} \mathrm{S}-5^{\circ}\right.$ $\mathrm{N}, 120-170^{\circ} \mathrm{W}$ ) during boreal winter. Figure S6 (in the Supplementary) shows a scatterplot of the CC_Diff index versus projected changes in the winter Niño-3.4 related simultaneous 

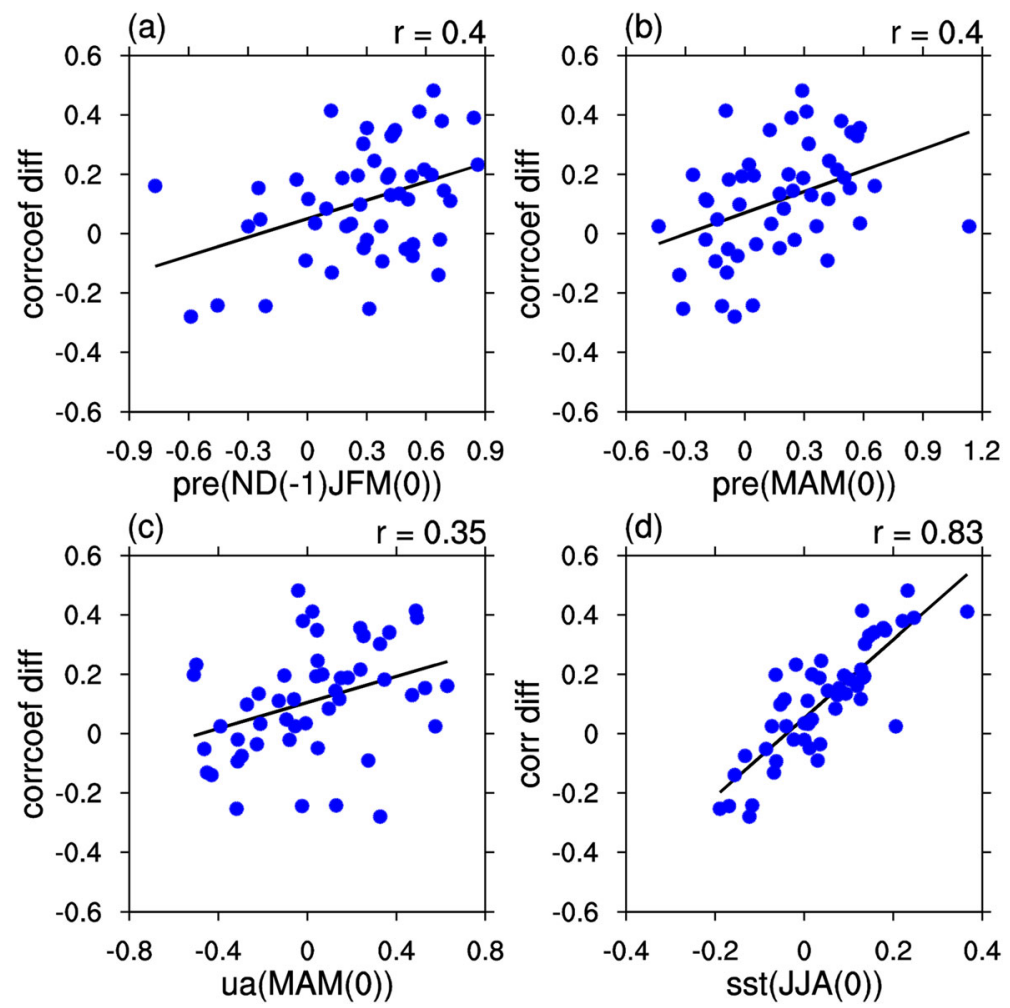

Fig. 9 Scatterplots of the CC Diff index versus projected changes in the winter NPO-related a ND(-1)JFM(0) precipitation anomalies averaged over $5-10^{\circ} \mathrm{N}, 155-175^{\circ} \mathrm{W} ; \mathbf{b} \operatorname{MAM}(0)$ precipitation anomalies averaged over $0-5^{\circ} \mathrm{N}, 175^{\circ} \mathrm{E}-145^{\circ} \mathrm{W}$; c MAM(0) zonal wind anomalies averaged over $5^{\circ} \mathrm{S}-5^{\circ} \mathrm{N}, 160^{\circ} \mathrm{E}-160^{\circ} \mathrm{W}$; and d $\mathrm{JJA}(0)$ SST anomalies averaged over $5^{\circ} \mathrm{S}-5^{\circ} \mathrm{N}, 120-180^{\circ} \mathrm{W}$

winter SST anomalies averaged in the Niño-3.4 region. The correlation between the two quantities among the 50 members is very weak. In addition, spatial patterns and phase lockings of the ENSO are generally similar between group A and group B over both periods of 19502003 and 2020-2073 (Figs. S7-8 in the Supplementary). Hence, the spread of the projected NPO-ENSO relations is not likely due to divergences of the projected changes of the amplitude, spatial pattern, and phase locking of the ENSO.

\section{Summary}

Previous observational and modeling studies have indicated that the wintertime NPO is an important extratropical atmospheric forcing for the following winter ENSO occurrence via the seasonal footprinting mechanism. This study explores the climate change projection of the winter NPO-ENSO connection using a 50-member large ensemble of climate simulations conducted with CanESM2. It is shown that majority of the 50 CanESM2 ensemble members can well capture the observed NPO-ENSO relationship over the historical simulation period from 1950 to 2003 . The MME of the 50 members have a good performance in simulating the 
winter NPO pattern, as well as the SFM process linking the winter NPO to its following winter ENSO.

These 50 ensemble simulations are further employed to investigate the projection of the winter NPO-ENSO relation in a warming climate, based on their RCP8.5 forced simulations. Results show that 36 out of the 50 members produce an enhancement of the winter NPOENSO connection in a warming climate, while the other 14 members project a weakened NPO-ENSO relation. The standard deviation of the correlation coefficient differences between 2020-2073 and 1950-2003 among the 50 members is also much larger than the MME difference. Hence, there exists a large uncertainty in projection of the winter NPO-ENSO connection in a warming climate due to internal climate variability. Further analyses indicate that the uncertainty in the climate projection primarily results from discrepancies in projected changes of the subtropical center of the winter NPO. Ensemble members with an enhancement (a reduction) of the subtropical center of winter NPO tend to project a strengthening (weakening) relation between the winter NPO and following winter ENSO. The large spread of projections of the winter NPO-associated atmospheric anomalies over the subtropical North Pacific would lead to various responses of projections of the NPO-related winter and spring precipitation anomalies over the tropical North Pacific, as well as spring westerly wind anomalies over the tropical western Pacific. These anomalies further contribute to the uncertainty in the projected winter NPO-related SST anomalies in the following summer and winter. Overall, internal climate variability largely influences the extratropical NPO impact on ENSO and hence the NPO-ENSO relationship in climate simulations needs to be used with caution.

Acknowledgments We thank three anonymous reviewers and the editor (Dr. L. D. Danny Harvey) for their constructive suggestions, which helped to improve the paper. This study is supported by the National Key Research and Development Program of China (Grant no. 2018YFA0605604), the National Natural Science Foundation of China grants (41605050, 41530425, and 41775080) and the Young Elite Scientists Sponsorship Program by the China Association for Science and Technology (2016QNRC001). We greatly appreciate the work of colleagues at the CCCma in the production of the model results analyzed here. We thank Dr. D. Jeong for helpful suggestions as internal reviews of the manuscript. The NCEP-NCAR reanalysis data are obtained from ftp://ftp.cdc.noaa.gov/Datasets/ncep.reanalysis.derived. The ERSSTv3b data are obtained from http://www. esrl.noaa.gov/psd/data/gridded.

Open Access This article is licensed under a Creative Commons Attribution 4.0 International License, which permits use, sharing, adaptation, distribution and reproduction in any medium or format, as long as you give appropriate credit to the original author(s) and the source, provide a link to the Creative Commons licence, and indicate if changes were made. The images or other third party material in this article are included in the article's Creative Commons licence, unless indicated otherwise in a credit line to the material. If material is not included in the article's Creative Commons licence and your intended use is not permitted by statutory regulation or exceeds the permitted use, you will need to obtain permission directly from the copyright holder. To view a copy of this licence, visit http://creativecommons.org/licenses/by/4.0/.

\section{References}

Alexander MA, Bladé I, Newman M, Lanzante JR, Lau NC, Scott JD (2002) The atmospheric bridge: the influence of ENSO teleconnections on air-sea interaction over the global oceans. J Clim 15:2205-2231

Alexander MA, Vimont DJ, Chang P, Scott JD (2010) The impact of extratropical atmospheric variability on ENSO: testing the seasonal footprinting mechanism using coupled model experiments. J Clim 23:28852901

Arora VK et al (2011) Carbon emission limits required to satisfy future representative concentration pathways of greenhouse gases. Geophys Res Lett 38:L05805 
Ashok K, Guan Z (2004) Individual and combined influences of ENSO and the Indian Ocean dipole on the Indian summer monsoon. J Clim 17:3141-3155

Barnett T, Dümenil L, Schlese U, Roeckner E, Latif M (1989) The effect of Eurasian snow cover on regional and global climate variations. J Atmos Sci 46:661-686

Battisti DS, Hirst AG (1989) Interannual variability in a tropical atmosphere-ocean model: influence of the basic state, ocean geometry and nonlinearly. J Atmos Sci 46:1687-1712

Bjerknes J (1969) Atmospheric teleconnections from the equatorial pacific. Mon Wea Rev 97:163-172

Chan JCL (2005) Interannual and interdecadal variations of tropical cyclone activity over the western North Pacific. Meteor Atmos Phy 89:143-152

Chen SF, Song LY (2019) The leading interannual variability modes of winter surface air temperature over Southeast Asia. Clim Dyn 52:4715-4734

Chen SF, Wu R (2018) Impacts of winter NPO on subsequent winter ENSO: sensitivity to the definition of NPO index. Clim Dyn 50:375-389

Chen W, Graf HF, Huang RH (2000) The interannual variability of East Asian winter monsoon and its relation to the summer monsoon. Adv Atmos Sci 17:48-60

Chen SF, Chen W, Wei K (2013) Recent trends in winter temperature extremes in eastern China and their relationship with the Arctic Oscillation and ENSO. Adv Atmos Sci 30:1712-1724

Chen SF, Yu B, Chen W (2014) An analysis on the physical process of the influence of AO on ENSO. Clim Dyn 42:973-989

Chen SF, Wu R, Chen W, Yu B, Cao X (2016) Genesis of westerly wind bursts over the equatorial western Pacific during the onset of the strong 2015-2016 El Niño. Atmos Sci Lett 17:384-391

Chen SF, Chen W, Yu B (2017) The influence of boreal spring Arctic Oscillation on the subsequent winter ENSO in CMIP5 models. Clim Dyn 48:2949-2965

Chen SF, Wu R, Chen W (2018) Modulation of spring northern tropical Atlantic sea surface temperature on the El Niño-Southern Oscillation-East Asian summer monsoon connection. Int J Climatol 38:5020-5029

Chen SF, Wu R, Chen W, Yu B (2020) Recent weakening of the linkage between the spring Arctic Oscillation and the following winter El Niño-Southern Oscillation. Clim Dyn 54:53-67

Chiang JCH, Sobel AH (2002) Tropical tropospheric temperature variations caused by ENSO and their influence on the remote tropical climate. J Clim 15:2616-2631

Christian JR et al (2010) The global carbon cycle in the CCCma earth system model CanESM1: preindustrial control simulation. J Geophys Res 115:G03014

Deser C, Phillips AS, Tomas RA, Okumura YM, Alexander MA, Capotondi A, Scott JD, Kwon YO, Ohba M (2012a) ENSO and Pacific decadal variability in the community climate system model version 4. J Clim 25: 2622-2651

Deser C, Knutti R, Solomon S, Phillips AS (2012b) Communication of the role of natural variability in future North American climate. Nat Clim Chang 2:775-779

Deser C, Phillips AS, Bourdette V, Teng H (2012c) Uncertainty in climate change projections: the role of internal variability. Clim Dyn 38:527-546

Deser C, Phillips AS, Alexander MA, Smoliak BV (2014) Projecting North American climate over the next 50 years: uncertainty due to internal variability. J Clim 27:2271-2296

Ding R, Li J, Tseng Y, Sun C, Guo Y (2015) The Victoria mode in the North Pacific linking extratropical sea level pressure variations to ENSO. J Geophys Res 120:27-45

Fisher RA (1921) On the 'probable error' of a coefficient of correlation deduced from a small sample. Metron 1: $3-32$

Graf HF, Zanchettin D (2012) Central Pacific El Niño, the "subtropical bridge," and Eurasian climate. J Geophys Res 117:D01102

Gray WM (1984) Atlantic seasonal hurricane frequency. Part I: El Niño and 30 mb quasi-biennial oscillation influences. Mon Wea Rev 112:1649-1668

He SP, Wang HJ (2013) Oscillating relationship between the East Asian winter monsoon and ENSO. J Clim 26: 9819-9838

Huang RH, Xu Y, Wang P, Zhou L (1998) The features of the catastrophic flood over the Changjiang River basin during the summer of 1998 and cause exploration. Climatic and Environmental Research 3:300-313

Huang R, Zhang R, Yan B (2001) Dynamical effect of the zonal wind anomalies over the tropical western Pacific on ENSO cycles. Sci China Ser D Earth Sci 44:1089-1098

Huang RH, Chen W, Yan BL, Zhang RH (2004) Recent advances in studies of the interaction between the east Asian winter and summer monsoons and ENSO cycle. Adv Atmos Sci 21:407-424

Jin FF (1997) An equatorial ocean recharge paradigm for ENSO. Part I: Conceptual model. J Atmos Sci 54:811829

Joshi MK, Ha KJ (2019) Fidelity of CMIP5-simulated teleconnection between Atlantic multidecadal oscillation and Indian summer monsoon rainfall. Clim Dyn 52:4157-4176 
Kalnay E, Kanamitsu M, Kistler R, Collins W, Deaven D, Gandin L, Iredell M, Saha S, White G, Woollen J, Zhu Y, Leetmaa A, Reynolds R, Chelliah M, Ebisuzaki W, Higgins W, Janowiak J, Mo KC, Ropelewski C, Wang J, Jenne R, Joseph D (1996) The NCEP/NCAR 40-year reanalysis project. Bull Am Meteorol Soc 77(3):437-471

Kay JE, Deser C, Phillips A, Mai A, Hannay C, Strand G, Arblaster JM, Bates SC, Danabasoglu G, Edwards J, Holland M, Kushner P, Lamarque JF, Lawrence D, Lindsay K, Middleton A, Munoz E, Neale R, Oleson K, Polvani L (2015) The community earth system model (CESM) large ensemble project: a community resource for studying climate change in the presence of internal climate variability. Bull Amer Meter Soc 96:1333-1349

Kirchmeier-Young MC, Zwiers FW, Gillett NP (2017) Attribution of extreme events in Arctic sea ice extent. J Clim 30(2):553-571

Kovats RS, Bouma MJ, Hajat S, Worral E, Haines A (2003) El Niño and health. Lancet 362:1481-1489

Kucharski F, Joshi MK (2017) Influence of tropical south Atlantic sea surface temperatures on the Indian summer monsoon in CMIP5 models. Quart J Roy Meteor Soc 143:1351-1363

Lau K, Weng H (2001) Coherent modes of global SST and summer rainfall over China: an assessment of the regional impacts of the 1997-98 El Niño. J Clim 14:1294-1308

Li CY (1990) Interaction between anomalous winter monsoon in East Asia and EI Niño events. Adv Atmos Sci 7:36-46

Linkin ME, Nigam S (2008) The north pacific oscillation-West Pacific teleconnection pattern: mature-phase structure and winter impacts. J Clim 21:1979-1997

McGregor GR, Ebi K (2018) El Niño southern oscillation (ENSO) and health: an overview for climate and health researchers. Atmos 9:282. https://doi.org/10.3390/atmos9070282

McPhaden MJ (2002) El Niño and La Niña: causes and global consequences. In: MacCracken MC, Perry JS (eds) Encyclopedia of global environmental change, vol 1. Wiley, Chicester, pp 353-370

Meng X, Rosenthal R, Rubin DB (1992) Comparing correlated correlation coefficients. Psychol Bull 111:172175

Mo KC (2000) Relationships between low-frequency variability in the southern hemisphere and sea surface temperature anomalies. J Clim 13:3599-3610

Nakamura T, Tachibana Y, Honda M, Yamane S (2006) Influence of the northern hemisphere annular mode on ENSO by modulating westerly wind bursts. Geophys Res Lett 33:L07709

Nakamura T, Tachibana Y, Shimoda H (2007) Importance of cold and dry surges in substantiating the NAM and ENSO relationship. Geophys Res Lett 34:L22703

Oluwole OSA (2015) El Nino-southern oscillation and cassava production in Tanzania and Brazil. Clim Chang 131:273-285

Park JY, Yeh SW, Kug JS, Yoon J (2013) Favorable connections between seasonal footprinting mechanism and El Niño. Clim Dyn 40:1169-1181

Philander SG (1990) El Niño, La Niña, and the southern oscillation, Volume 46. Academic Press, London 289p

Rondeau-Genesse G, Braun M (2019) Impact of internal variability on climate change for the upcoming decades: analysis of the CanESM2-LE and CESM-LE large ensembles. Clim Chang 156:299-314

Sigmond M, Fyfe JC (2016) Tropical Pacific impacts on cooling North American winters. Nat Clim Chang 6: 970-974

Smith TM, Reynolds RW, Peterson TC, Lawrimore J (2008) Improvements to NOAA's historical merged landocean surface temperature analysis (1880-2006). J Clim 21(10):2283-2296

Song LY, Li Y, Duan W (2016) The influence of boreal winter extratropical North Pacific oscillation on Australian spring rainfall. Clim Dyn 47:1181-1196

Song LY, Chen SF, Chen W, Chen XL (2017) Distinct impacts of two types of La Niña events on Australian summer rainfall. Int J Climatol 37:2532-2544

van Vuuren DP, Edmonds J, Kainuma M, Riahi K, Thomson A, Hibbard K, Hurtt GC, Kram T, Krey V, Lamarque JF, Masui T, Meinshausen M, Nakicenovic N, Smith SJ, Rose SK (2011) The representative concentration pathways: an overview. Clim Chang 109:5-31

Vimont DJ, Battisti DS, Hirst AC (2001) Footprinting: a seasonal connection between the tropics and midlatitudes. Geophys Res Lett 28:3923-3926

Vimont DJ, Wallace JM, Battisti DS (2003a) The seasonal footprinting mechanism in the Pacific: implications for ENSO. J Clim 16:2668-2675

Vimont DJ, Battisti DS, Hirst AC (2003b) The seasonal footprinting mechanism in the CSIRO general circulation models. J Clim 16:2653-2667

Wallace JM, Gutzler DS (1981) Teleconnections in the geopotential height field during the northern hemisphere winter. Mon Wea Rev 109:784-812 
Wallace JM, Deser C, Smoliak BV, Phillips AS (2014) Attribution of climate change in the presence of internal variability. Climate change: multidecadal and beyond. In: Chang CP et al (eds) Asia-Pacific weather and climate series, vol 6. World Scientific

Wang B, Wu R, Fu X (2000) Pacific-East Asia teleconnection: how does ENSO affect East Asian climate? J Clim 13:1517-1536

Wang HJ, He SP, Liu JP (2013) Present and future relationship between the east Asian winter monsoon and ENSO: results of CMIP5. J Geophys Res 118:1-16

Wang X, Chen M, Wang C, Yeh S, Tan W (2019a) Evaluation of performance of CMIP5 models in simulating the North Pacific oscillation and El Niño Modoki. Clim Dyn 52:1383-1394

Wang X, Guan C, Huang R, Tan W, Wang L (2019b) The roles of tropical and subtropical wind stress anomalies in the El Niño Modoki onset. Clim Dyn 52(11):6585-6597

Wu R, Kinter JL (2010) Atmosphere-ocean relationship in the midlatitude North Pacific: seasonal dependence and east-west contrast. J Geophys Res 115:D06101

Wu R, Hu ZZ, Kirtman BP (2003) Evolution of ENSO-related rainfall anomalies in East Asia. J Clim 16:37423758

Xie SP, Philander SGH (1994) A coupled ocean-atmosphere model of relevance to the ITCZ in the eastern Pacific. Tellus A 46:340-350

Xie SP, Hu K, Hafner J, Tokinaga H, Du Y, Huang G, Sampe T (2009) Indian Ocean capacitor effect on IndoWestern Pacific climate during the summer following El Niño. J Clim 22:730-747

Yeh SW, Wang X, Wang CZ, Dewitte B (2015) On the relationship between the North Pacific climate variability and the Central Pacific El Niño. J Clim 28:663-677

Yu JY, Kim ST (2011) Relationships between extratropical sea level pressure variations and the Central Pacific and eastern Pacific types of ENSO. J Clim 24:708-720

Yu B, Zwiers F (2007) The impact of combined ENSO and PDO on the PNA climate: a 1,000-year climate modeling study. Clim Dyn 29:837-851

Zhai P, Yu R, Guo Y, Li Q, Ren X, Wang Y, Xu W, Liu Y, Ding Y (2016) The strong El Niño of 2015/16 and its dominant impacts on global and China's climate. J Meteorol Res 30:283-297

Zhao W, Chen SF, Chen W, Yao SL, Nath D, Yu B (2019) Interannual variations of the rainy season withdrawal of the monsoon transitional zone in China. Clim Dyn 53:2031-2046

Zheng XT, Hui C, Yeh SW (2018) Response of ENSO amplitude to global wamring in CESM large ensemble: uncertainty due to internal variabitiy. Clim Dyn 50:4019-4035

Publisher's note Springer Nature remains neutral with regard to jurisdictional claims in published maps and institutional affiliations.

\section{Affiliations}

\section{Shangfeng $\mathrm{Chen}^{1} \cdot$ Bin $\mathrm{Yu}^{2}$}

1 Center for Monsoon System Research, Institute of Atmospheric Physics, Chinese Academy of Sciences, Beijing, China

2 Climate Research Division, Environment and Climate Change Canada, Toronto, ON, Canada 